\title{
DETENTION OF ASYLUM SEEKERS THROUGH THE PRACTICE OF THE COURT OF JUSTICE OF THE EUROPEAN UNION ON THE EXAMPLE OF THE REPUBLIC OF HUNGARY AND THE PERSPECTIVES OF THE NEW PACT ON MIGRATION AND ASYLUM
}

\author{
Marina Čepo, PhD, Teaching and Research Assistant \\ Academy of Arts and Culture, Josip Juraj Strossmayer University of Osijek \\ Ulica kralja Petra Svačića 1/f, Osijek, Croatia \\ mcepo@uaos.hr
}

\begin{abstract}
Restrictions on freedom of movement, in particular the detention of asylum seekers as the most severe form of such restrictions, constitute an interference with fundamental human rights and must be approached with particular care. In view of the migration and refugee crisis, the Republic of Hungary has begun to amend its asylum legislation, thus tightening the conditions for the detention of asylum seekers. The introduction of the provision establishing that asylum may be sought only in transit zones has also led to the gradual detention of asylum seekers in transit zones, which Hungary did not consider as detention. This issue was brought before the Court of Justice of the European Union (hereinafter: CJEU), which drastically changed the path taken by the Hungarian government when it comes to detaining asylum seekers. What the CJEU has found is that leaving people in transit zones without the right to free movement is to be considered detention, even though they are not specialized detention facilities. The CJEU ordered that such a practice must cease immediately. Therefore, this paper will examine the Hungarian practice following the judgment of the CJEU. The CJEU has taken a major step towards protecting the rights of asylum seekers as regards detention, and the EU recently adopted amendments as part of the new Pact on Migration and Asylum aimed at improving the existing asylum system. The second part of the paper analyzes the provisions of the new Pact on Migration and Asylum related to detention in order to determine whether the proposed amendments contribute to the Common European Asylum System and the protection of the human rights of asylum seekers or represent a step backwards.
\end{abstract}

Keywords: asylum, detention, Hungary, CJEU, New Pact on Migration and Asylum 


\section{INTRODUCTION}

The detention of asylum seekers in the European Union (hereinafter: the EU) is one of the issues very often associated with human rights violations. The actions of Member States following the migration and refugee crisis in the EU, as well as changes in national legislation, have led to violations of the rights of asylum seekers under international and European refugee law, in particular the freedom of movement within the state in which they have applied for asylum. At the very beginning of the paper, the provisions of European law regulating the freedom of movement of asylum seekers and its restriction with regard to the application of the detention measure will be analyzed. The paper will further discuss the application of the detention measure in the Republic of Hungary (hereinafter: Hungary), a state that, following the refugee and migration crisis in the EU, raised a physical barrier at the state border and amended its asylum legislation in a manner inconsistent with international and European law. The CJEU analyzed the actions of Hungary when it comes to conducting asylum procedures in transit zones and the application of detention measures, thus determining the most significant deviations from international and European law. With this ruling, the CJEU took a major step towards protecting the rights of asylum seekers as regards freedom of movement within the state in which they applied for asylum. Shortly after the Court ruling, the EU proposed a number of amendments presented in the new Pact on Migration and Asylum (hereinafter: PMA) with a view to improving the existing asylum and migration management system. The proposed measures significantly change the existing system and bring a completely new approach to the asylum system in the EU. Therefore, the second part of the paper analyzes the provisions of the PMA related to the detention of asylum seekers in the border procedure in order to determine whether the proposed amendments contribute to the Common European Asylum System (hereinafter: CEAS) and the protection of the human rights of asylum seekers or represent a step backwards. At the very end of the paper, certain guidelines are given in relation to the detention of asylum seekers under European legislation, which could have a positive impact on the creation of the CEAS and the protection of the human rights of asylum seekers, in particular the right to freedom of movement. Therefore, the hypothesis of this paper is that Hungary's actions after the migration and refugee crisis and its changes in legislation related to the rights of asylum seekers are in complete contradiction with European and international legal norms when it comes to restricting the freedom of movement of asylum seekers and applying detention measures. Moreover, the paper will try to prove that the PMA provisions related to the detention of asylum seekers in the border procedure do not contribute to the CEAS and the protection of the human rights of asylum seekers, but represent a step backwards. The question is whether the provisions on the implementation of the asylum pro- 
cedure at the EU border, as well as the automatic detention of an asylum seeker during that time, are in line with recent CJEU case law.

\section{FREEDOM OF MOVEMENT OF ASYLUM SEEKERS IN THE STATE IN WHICH THEY APPLIED FOR ASYLUM AND GROUNDS FOR RESTRICTIONS IN EUROPEAN LAW - DE LEGE LATA}

The EU Charter of Fundamental Rights (hereinafter: the EU Charter) guarantees in Article 6 everyone the right to liberty and security of person. Despite the efforts made by the EU legislator to define the concept of detention and the efforts of the CJEU to interpret the set legal framework, a lack of results has been observed. The EU legal framework, unlike the European Court of Human Rights (hereinafter: ECtHR), links the concept of detention to the deprivation or restriction of freedom of movement, and not to the deprivation of the right to physical freedom of every human being. The Dublin system is the oldest cornerstone of the CEAS, established to harmonize Member States' asylum policies and procedural issues when it comes to asylum. ${ }^{1}$ The Regulation establishing the criteria and mechanisms for determining the Member State responsible for examining an application for international protection lodged in one of the Member States by a third-country national or a stateless person (hereinafter: Dublin III Regulation) does not define the freedom of movement of asylum seekers but proclaims that the detention of applicants should be applied following the fundamental principle that a person should not be detained simply because he or she seeks international protection. ${ }^{2}$ Detention should be as short as possible and in accordance with the principle of proportionality, in particular Article 31 of the Convention Relating to the Status of Refugees ${ }^{3}$ (hereinafter: 1951 Convention). ${ }^{4}$ As regards general safeguards concerning detention and conditions for detention, reference is made to the application of the Directive on minimum standards for the qualification and status of third-country nationals or stateless persons as refugees or as persons

1 For more details on the Dublin system see: Maiani, F., The Dublin III Regulation: A New Legal Framework for a More Humane System?, in: Chetail,V.; De Bruycker, P.; Maiani, F. (eds.), Reforming the Common European Asylum System - The New European Refugee Law, Brill Nijhoff, Leiden, Boston, 2016.

2 Regulation (EU) No 604/2013 of the European Parliament and of the Council of 26 June 2013 establishing the criteria and mechanisms for determining the Member State responsible for examining an application for international protection lodged in one of the Member States by a third-country national or a stateless person, OJ L 180 (Regulation Dublin III) Preamble, Recital 20.

3 Convention relating to the Status of Refugees, adopted on 28 July 1951 by General Assembly Resolution 429 (V) of 14 October 1950, entered into force on 22 April 1954.

4 Costello, C., Human Rights of Migrants and Refugees in European Law, Oxford University Press, 2016. 
who otherwise need international protection and the content of the protection granted $^{5}$ (hereinafter: Directive on minimum standards) and to detention procedures under the Dublin III Regulation. ${ }^{6}$ Article 28 of the Dublin III Regulation provides for an exception to freedom of movement for asylum seekers, i.e. detention for transfer when there is a high risk of absconding. Detention, in this case, must be as short as possible and last only as long as is reasonably necessary. ${ }^{7}$ All EU institutions apply the principle of proportionality following the Protocol on the application of the principles of subsidiarity and proportionality. ${ }^{8}$ The principle of proportionality is the cornerstone of the individualized procedure on which the detention decision is based, and a detention measure that is not necessary in an individual case is not accepted as such. ${ }^{?}$

The perception of the legislator that is necessary to define the rules for issuing a detention order is paradoxical. In a system that assigns responsibility for asylum applications and which should in principle also protect the rights of asylum seekers, detention or the use of other measures restricting liberty would not be necessary if the system is based on correct assumptions, provides equal conditions, outcomes and comparable rights for persons who exercise the right to international protection. ${ }^{10}$ Therefore, according to Hruschka and Maiani, the provision of Article 28 in itself shows the imperfection of the system and the introduction of detention can only be considered a "transitional measure" into a system that can function without the use of coercion. ${ }^{11}$

The Directive laying down standards for the reception of applicants for international protection ${ }^{12}$ (hereinafter: Reception Directive) is also relevant in determin-

5 Council Directive 2004/83/EC on minimum standards for the qualification and status of third-country nationals or stateless persons as refugees or as persons who otherwise need international protection and the content of the protection granted, 2004, OJ L 304 (Qualification Directive).

6 Regulation Dublin III, Preamble, Recital 20.

7 Regulation Dublin III, Art. 28(2)(3).

8 Consolidated versions of the Treaty on the Functioning of the European Union Protocol (No. 2) on the application of the principles of subsidiarity and proportionality, OJ C 202.

$9 \quad$ Wilsher, D., Immigration Detention: Law, History, Politics, Cambridge University Press, 2012, p. 336.

10 See: Filzwieser, C.; Sprung, A., Dublin III-Verordnung, Das Europäische Asylzuständigkeitssystem - Stand: 1. February 2014, BWV Berliner-Wissenschaft, 2014.

11 Hruscha, B.; Maiani, F., Regulation (EU) No 604/2013 of the European Parliament and of the Council of 26 June 2013 establishing the criteria and mechanisms for determining the Member State responsible for examining an application for international protection lodged in one of the Member States by a third-country national or a stateless person (recast), in: Hailbronner, K.; Thym, D., (eds.), EU Immigration and Asylum Law, A Commentary, 2nd edition, C.H.Beck/Hart/Nomos, 2016, pp. 1478; Bender, D.; Hocks, S., Eilrechtsschutz und Selbsteintrittspflicht im Dublin-Verfahren, Asylmagazin, 2010, p. 223.

12 Directive 2013/33/EU of the European Parliament and of the Council of 26 June 2013 laying down standards for the reception of applicants for international protection (recast) OJ L 180 (Reception 
ing the conditions of detention and treatment in situations where it is necessary to restrict the freedom of movement of asylum seekers and to order their detention, and in the procedures provided for by the Member States. Thus, Article 7(1) of the Reception Directive guarantees freedom of movement for applicants "within the territory of the host Member State or within an area assigned to them by that Member State". It is this provision that creates ambiguity about the freedom of movement of asylum seekers because it is provided for in the first part of the sentence, whereas in the second part of the sentence it is limited to the area designated by the state. Article 7 of the Reception Directive regulates two areas that are closely linked but not identical. The first concerns freedom of movement and the circumstances under which that freedom may be restricted, while the second area concerns the place of residence of asylum seekers. These two areas and the difference in their interpretations are not clearly stated in the provision of Article 7 and it is necessary to amend the provision in terms of a clearer definition of freedom of movement, restriction of freedom of movement, and place of residence of asylum seekers. Article 7 of the 2003 Reception Directive was also highly debated during the pre-adoption procedure. ${ }^{13}$ The article was criticized for giving the Member States an open path to the complete annulment of the right to liberty. It is precisely this kind of discretion given to the Member States that also raises the question of the compatibility of Article 7(1) of the Reception Directive with Article 31(2) of the 1951 Convention. ${ }^{14}$ This type of restriction of the movement of asylum seekers to a specific territorial part of a Member State may consequently have an impact on access to education, health care, and employment. Therefore, such territorial restrictions on movement should be used rarely; however, they should not depend on the size of the area restricting the freedom of movement of asylum seekers, but on the infrastructure of such an area and the availability of all necessary services and address the needs of asylum seekers. The vast majority of asylum seekers are accommodated in reception centers located in the Member States and funded by the state. As these capacities are limited and often insufficient, it is clear that there is a need to relocate asylum seekers to other parts of the Member State where there are spare capacities, and in that case, such a decision is considered justified. What Peek and Tsourdi see as a problem, however, is the determination of residence by the state in situations where asylum seekers can afford private accommodation and finance it themselves or have family and friends with whom they can stay. In that case, the limited capacities in the reception

\section{Directive).}

13 FRA and Council of Europe, Handbook on European Law relating to asylum, borders and immigration, 2013, p. 138.

14 See: Marx, R., Article 26, in: Zimmermann, A. (ed.), The 1951 Convention Relating to the Status of Refugees and its 1967 Protocol: A Commentary, Oxford University Press, 2011, p. 1163-1164. 
centers cannot justify the determination of the asylum seekers' place of residence and likewise these decisions cannot be based on the public interest. ${ }^{15}$ Moreover, although the system of reception of asylum seekers depends on the capacities available in the reception centers, this does not mean that the general transfer of all asylum seekers who are unable to secure accommodation and living conditions is justified. Therefore, the Member States which do not provide for exceptions to the determination of residence in individual cases, including those asylum seekers who can secure accommodation on their own, are considered to be in breach of the Reception Directive. ${ }^{16}$ Article 8(3) of the Reception Directive prescribes specific grounds for detention: to verify identity or nationality, to determine those elements of an asylum application which cannot be obtained in the absence of detention, to decide on the right of an asylum seeker to enter the state territory, due to the implementation of the return procedure and for reasons of national security and public order. The Directive on common standards and procedures in Member States for returning illegally staying third-country nationals (hereinafter: Return Directive) provides that, if less coercive measures cannot be applied in a particular case, Member States may detain a third-country national to ensure the return procedure, especially when there is a risk of absconding or a particular third-country national avoids or obstructs preparations for the return. ${ }^{17}$ In the El Dridi case, the CJEU emphasized that detention should be used as a last resort. ${ }^{18}$ Any detention may last only as long as is necessary to fulfill the purpose of such detention. The possibility of detaining a person for reasons of public order and public security cannot be based on the Return Directive. Given that Article 7(1) of the proposal to amend the Return Directive gives a certain discretion to the Member States to restrict the freedom of movement of asylum seekers and the resulting practice, the

15 Peek, M.; Tsourdi, L., Asylum Reception Conditions Directive 2012/33/EU, Article 7, in: Hailbronner, K.; Thym D., (eds.), EU Immigration and Asylum Law, A Commentary, 2nd edition, C. H. Beck/ Hart/Nomos, 2016, p. 1409.

16 Meyer, T., Mindestaufnahmebedingungen für Asylbewerber: Nivelierung auf niedrigem Niveau oder Fortschritt für eine gemeinsame Asylpolitik in Europa?, in: Neue Zeitschrift für Verwaltungsrecht, 2004, p. 549.

17 Directive 2008/115/EC of the European Parliament and of the Council of 16 December 2008 on common standards and procedures in Member States for returning illegally staying third-country nationals, OJ L 348 (Return Directive) Art. 15(1).

18 Case C-61/11 Hassen El Dridi, alias Soufi Karim [2011], Reference for a preliminary ruling: Corte d'appello di Trento - Italy, paragraph 39: “...Member States must carry out the removal using the least coercive measures possible. It is only where, in the light of an assessment of each specific situation, the enforcement of the return decision in the form of removal risks being compromised by the conduct of the person concerned that the Member States may deprive that person of his liberty and detain him", as well as paragraph 41: "...in order to enforce the return decision, a gradation which goes from the measure which allows the person concerned the most liberty, namely granting a period for his voluntary departure, to measures which restrict that liberty the most, namely detention in a specialised facility". 
question arises as to whether that provision complies with Article 26 of the 1951 Convention, which prescribes only the restriction of freedom of movement applicable to aliens in the same situation. ${ }^{19}$ What De Bruycker et. al. see as a problem is compliance with international sources of law, such as the European Convention for the Protection of Human Rights and Fundamental Freedoms ${ }^{20}$ (hereinafter: ECHR), the International Covenant on Civil and Political Rights ${ }^{21}$ and the 1951 Convention, as well as the lack of proportionality provisions that must be taken into account when determining measures restricting the freedom of movement of asylum seekers. Restricting freedom of movement to ensure a faster and more efficient examination of asylum applications is not in line with international regulations and these circumstances should be taken into account when deciding on the proposal to amend the Return Directive. ${ }^{22}$

The Directive on standards for the qualification of third-country nationals or stateless persons as beneficiaries of international protection, for a uniform status for refugees or for persons eligible for subsidiary protection, and for the content of the protection granted ${ }^{23}$ (hereinafter: Qualifications Directive) guarantees freedom of movement for beneficiaries of international protection "within their territory under the same conditions and with the same restrictions as those provided for other third-country nationals legally resident in their territories." ${ }^{24}$ What follows from that provision is a reference to the national rules of the Member States as regards restrictions on the freedom of movement of beneficiaries of international protection and those in the process of obtaining international protection. The question arises as to where and under what conditions asylum seekers will stay while their status is being decided, and how to proceed when it comes to a family with minor children. Another question that arises is the situation when the asylum seeker is an unaccompanied minor. Will his or her freedom of movement be restricted because the minor is without the supervision of a responsible adult, and where will he or she normally be accommodated while waiting a decision on his or her application?

19 Marx, op. cit., note 14.

20 Council of Europe, European Convention for the Protection of Human Rights and Fundamental Freedoms, as amended by Protocols Nos. 11 and 14, 4 November 1950, ETS 5.

21 UN General Assembly, International Covenant on Civil and Political Rights, 16 December 1966, United Nations, Treaty Series, vol. 999.

22 De Bruycker, P.; Bloomfield, A.; Tsourdi, E. L.; Pétin, J., Alternatives to Immigration and Asylum Detention in the EU - Time for Implementation, Odysseus - Academic Network for Legal Studies on Immigration, 2015, p. 35.

23 Directive 2011/95/EU of the European Parliament and of the Council of 13 December 2011 on standards for the qualification of third-country nationals or stateless persons as beneficiaries of international protection, for a uniform status for refugees or for persons eligible for subsidiary protection, and for the content of the protection granted (recast), OJ L 337 (Qualifications Directive).

24 Qualifications Directive, Art. 33. 
Article 26 of the Directive on common procedures for granting and withdrawing international protection ${ }^{25}$ (hereinafter: Common Procedures Directive) stipulates that "Member States shall not hold a person in detention simply because he or she is an applicant" and that if the applicant is detained, "Member States shall ensure that there is a possibility of speedy judicial review in accordance with Directive 2013/33/EU." It is clear that the Common Procedures Directive calls for the application of the Reception Directive when it comes to determining the measure of detention of asylum seekers but reiterates the importance of the fact that no one may be detained or deprived of freedom of movement simply because he or she is an asylum seeker. The purpose of the Common Procedures Directive is to ensure that all asylum seekers have access to the asylum procedure and, in part, to enable interpreters to ensure that the authorities in charge of the procedure are sure that the third-country national wishes to apply for asylum. This also applies to asylum seekers in detention institutions. ${ }^{26}$

Several problems exist in the current EU asylum system when it comes to restricting the freedom of movement of asylum seekers and enforcing detention measures. The biggest problem is the different interpretations of the provisions by the Member States and the use of national security as a pretext for many detention decisions. It is precisely because of the perceived shortcomings of the asylum system that the EU has embarked on the reform and adoption of the PMA, which will be discussed later in this paper.

\section{DETENTION OF ASYLUM SEEKERS IN THE REPUBLIC OF HUNGARY}

Article 27 of the Hungarian Constitution states that everyone legally residing in Hungary has the right to choose their place of residence as well as freedom of movement. ${ }^{27}$ Thus, the Hungarian legislator implemented the provisions of the 1951 Convention and Article 26 on freedom of movement. For the purpose of conducting the asylum procedure and ensuring transfers under the Dublin pro-

25 Directive 2013/32/EU of the European Parliament and of the Council of 26 June 2013 on common procedures for granting and withdrawing international protection, OJ L 180 (Common Procedures Directive).

26 "In order to facilitate access to the examination procedure at border crossing points and in detention facilities, information should be made available on the possibility to apply for international protection. Basic communication necessary to enable the competent authorities to understand if persons declare their wish to apply for international protection should be ensured through interpretation arrangements." Common Procedures Directive, Recital 28.

27 Magyarország Alaptörvénye from April 25, 2011, available at: [https://nemzetikonyvtar.kormany.hu/ download/8/00/50000/horv\%C3\%A1t-magyar_nyomdai.pdf], Accessed 2 February 2021. 
cedure, the Administration may detain the asylum seeker to establish his or her identity, if expulsion proceedings have been initiated or if there are reasonable grounds for believing that the asylum seeker is seeking international protection solely in order to delay or impede the enforcement of the expulsion decision, in order to establish the facts and circumstances on which the asylum application is based if those facts and circumstances cannot be established without detention, in particular where there is a risk of absconding. It is also possible to impose this measure when detention is necessary to protect national security or public order if the application is lodged at an airport, when detention is necessary to secure surrender procedures under the Dublin III Regulation and when there is a serious risk of absconding. Detention may be determined on a case-by-case basis, and only if its purpose cannot be ensured by the application of an availability measure. Before imposing a detention measure, the Administration shall consider whether the purpose can be achieved by applying a less restrictive measure. ${ }^{28} \mathrm{An}$ unaccompanied minor cannot be detained under Hungarian law. The detention of a family with a minor can only be determined as a final measure, taking into account primarily the best interests of the child. ${ }^{29}$

As regards the effectiveness and oversight of the national judiciary over the legality of detention decisions, the Hungarian Helsinki Committee (hereinafter: HHC) concludes in an analysis of sixty-four court decisions conducted in 2014 that such oversight is completely ineffective. ${ }^{30}$ The HHC has systematically criticized the shortcomings of detaining asylum seekers. ${ }^{31}$ The decision of the District Court of Nyírbátor is an extreme example showing the lack of individualization of each case precisely because it contained incorrect personal data such as the name, date of birth, or nationality of an asylum seeker. ${ }^{32}$ Moreover, four national court decisions contained a date of birth indicating an age below 18 years. However, no decision

2007 évi LXXX törvény a menedékjogról (Asylum Act), Art. 31 (A) (1) (2) (3).

2007 évi LXXX törvény a menedékjogról (Asylum Act), Art.31 (B) (1) (2).

30 See: Hungarian Helsinki Committee, Information Note on asylum-seekers in detention and in Dublin procedures in Hungary, 2014.

31 See: Hungarian Helsinki Committee, Briefing paper for the European Committee for the Prevention of Torture and Inhuman or Degrading Treatment or Punishment (CPT) on the occasion of the CPT's periodic visit to Hungary, 2013, Chapter 5.1, available at: [http://helsinki.hu/wp-content/uploads/HHC_briefing-paper_CPT_periodic_visit_28March2013_FINAL.pdf], Accessed 27 January 2021; Hungarian Helsinki Committee, Access to Protection Jeopardized - Information note on the treatment of Dublin returnees in Hungary, 2011, Chapter 4-5, available at: [http://helsinki.hu/en/access-to-protection-jeopardised-2], Accessed 27 January 2021; Hungarian Helsinki Committee, Stuck in Jail - Immigration detention in Hungary in 2010/2011, available at: [http://helsinki.hu/wp-content/uploads/HHC-immigration-detention_ENG_final.pdf], Accessed 27 January 2021.

32 According to: Nyírbátor District Court, Decisionsno. 1.Ir.214/2014/3., 9.Ir.350/2014/3., 1.Ir.728/2013/5. and 9.Ir.335/2014/3. 
called into question the legality of detaining an asylum seeker under the age of 18 , nor did it involve an age assessment procedure or proof of the legal age of a particular asylum seeker. ${ }^{33}$ According to an analysis conducted by the Hungarian Supreme Court, out of approximately 5,000 decisions made in 2011 and 2012, only in three cases was a particular detention measure overturned, while the rest simply extended such a measure without any particular justification. ${ }^{34}$ It is precisely because of such inconsistencies and legal shortcomings in the decisions of national courts that the ECtHR has examined 7 cases related to the arbitrary detention of asylum seekers in 2019 alone. ${ }^{35}$ These cases of omission were suspended pending a decision by the CJEU on whether holding asylum seekers in a transit zone was equated with deprivation of liberty and detention. Now that the CJEU has ruled that such detention is tantamount to deprivation of liberty, it remains to be seen how the Hungarian authorities will act on that decision. In 2018, the Administrative and Labor Court in Szeged annulled several decisions on the placement of asylum seekers in transit zones, although such a practice did not last longer than the beginning of 2019. ${ }^{36}$ There are three detention facilities: Debrecen, Békéscsaba and Nyírbátor, with a total capacity of 472 places. ${ }^{37}$ As of March 28, 2017, all asylum seekers entering the transit zones of Röszke and Tompa remain de facto detained, although the Hungarian authorities refuse to acknowledge that this is a form of detention. The fact that asylum seekers within transit zones have been deprived of their freedom of movement is also confirmed by the UN Working Group on Arbitrary Detention (UNWGAD), ${ }^{38}$ the European Committee for the Prevention of Torture (CPT), ${ }^{39}$ the UN High Commissioner for Refugees

33 According to: Nyírbátor District Court, Decisionno. 1.Ir.46/2014/3., Debrecen District Court, Decisionsno. 68. Beü.94/2014/4-I., 68.Beü.108/2014/4, 68.Beü.104/2014/4. and 68.Beü.1087/2014/4.

34 Supreme Court, Advisory Opinion of the Hungarian Supreme Court, adopted on 30 May 2013 and approved on 23 September 2013.

35 Supreme Court, Advisory Opinion of the Hungarian Supreme Court, adopted on 30 May 2013 and approved on 23 September 2013. Ahmed AYAD v. Hungary and four joint applications [2015] Application no. 7077/15, 26250/15, 26819/15, 32038/15, 48139/16; S.B. v. Hungary [2017] Application no. 15977/17; Dragon DSHIJRI v. Hungary [2016] Application no. 21325/16

36 According to: District Court of Szeged, Decision no. 6.K.27.060/2018/8; District Court of Szeged, Decision no. 44.K.33.689/2018/11.

37 Asylum Information Database, Country Report 2015.: Hungary, European Council of Refugees and Exiles, available at: [https://www.asylumineurope.org/sites/default/files/report-download/aida_hu_ update.iv_0.pdf], Accessed 1 March 2021.

38 UNWGAD, 'UN human rights experts suspend Hungary visit after access denied', 15 November 2018, available at: [https://bit.ly/2B7X5Pu], Accessed 12 April 2021.

39 CPT, Report on the visit to Hungary from 20 to 26 October 2017, CPT/Inf (2018) 42, 18 September 2018, available: [https://bit.ly/2TTgsTq.], Accessed 1 March 2021. 
(UNHCR),${ }^{40}$ the UN Human Rights Committee (UNHCR) ${ }^{41}$ the UN High Commissioner for Human Rights, ${ }^{42}$ the UN Special Rapporteur on the Human Rights of Migrants ${ }^{43}$ the European Commission ${ }^{44}$ and the Council of Europe Commissioner for Human Rights. ${ }^{45}$

The following is an analysis and statistical presentation of the decisions on restricting the freedom of movement of asylum seekers and imposing a detention measure in Hungary in the period from 2015 to 2019.

Table no. 1. Restrictions on the freedom of movement of asylum seekers and detention measures in Hungary in the period from 2015 to 2019

\begin{tabular}{|l|c|c|c|c|c|}
\hline & $\mathbf{2 0 1 5}$ & $\mathbf{2 0 1 6}$ & $\mathbf{2 0 1 7}$ & $\mathbf{2 0 1 8}$ & $\mathbf{2 0 1 9}$ \\
\hline Restrictions on the freedom of move- & $\begin{array}{c}13,202 \\
(100 \%)\end{array}$ & $\begin{array}{c}57,517 \\
(100 \%)\end{array}$ & $\begin{array}{c}1,567 \\
(100 \%)\end{array}$ & $\begin{array}{c}14 \\
(100 \%)\end{array}$ & $\begin{array}{c}40 \\
(100 \%)\end{array}$ \\
\hline ment of asylum seekers & $\begin{array}{c}1,829 \\
(13.85 \%)\end{array}$ & $\begin{array}{c}2,621 \\
(4.55 \%)\end{array}$ & $\begin{array}{c}391 \\
(24.95 \%)\end{array}$ & $\begin{array}{c}7 \\
(50 \%)\end{array}$ & $\begin{array}{c}0 \\
(0 \%)\end{array}$ \\
\hline \multirow{2}{*}{ Alternation } & 11,373 & 54,615 & 1,176 & 7 & 40 \\
& $(86.14 \%)$ & $(94.78 \%)$ & $(75.04 \%)$ & $(50 \%)$ & $(100 \%)$ \\
\hline
\end{tabular}

Source ${ }^{46}$

From Table no. 1 it follows that, in 2015, the measure of restriction of freedom of movement was imposed in 13,202 (7.50\%) cases out of a total of 175,960 applications filed that year, of which in $1,829(1.03 \%)$ cases the measure of detention of asylum seekers was imposed, while in $11,373(6.47 \%)$ cases an alternative measure of detention was imposed. What is particularly interesting in the Hungarian system, and what has certainly influenced the changes in the national asylum system, is the fact that in 2016 there were 29,432 asylum applications in Hungary,

40 UNHCR, 'UNHCR Chief visits Hungary, calls for greater access to asylum, end to detention and more solidarity with refugees”.2017, available at: [http://bit.ly/2y2BnsC.], Accessed 1 March 2021.

41 Human Rights Committee, Concluding observations on the sixth periodic report of Hungary, CCPR/C/HUN/CO/6, 2018., available at: [https://bit.ly/2TWDzwu.], Accessed 1 March 2021.

42 UN Office of the High Commissioner for Human Rights, Press briefing notes on Iran and Hungary, 2019., available at: [http://bit.ly/38h8pXr.], Accessed 1 March 2021.

$43 \mathrm{OHCHR}$, End of visit statement of the UN Special Rapporteur on the human rights of migrants, Felipe González Morales, 2019., available at: [http://bit.ly/2tqOHcX.], Accessed 1 March 2021.

44 European Commission, Migration and Asylum: Commission takes further steps in infringement procedures against Hungary, 2018., available at: [https://bit.ly/2uMEJ2c], Accessed 1 March 2021.

45 Commissioner for Human Rights Of The Council Of Europe, Report following visit to Hungary from 4 to 8 February 2019, 2019., available at: [http://bit.ly/30upiLp], Accessed 1 March 2021.

46 Analysis made based on the processing of data contained in the reports from 2015 to 2019 in Asylum Information Database, Country Report: Hungary, European Council of Refugees and Exiles, available at: [https://www.asylumineurope.org/reports/country/hungary], Accessed 1 March 2021. 
and the number of measures restricting freedom of movement imposed that year was 57,517, of which in 2,621 (4.55\%) cases a detention measure was imposed, while in 54,615 (94.78\%) cases an alternative detention measure was imposed. The existence of such illogicalities in the Hungarian system can only presuppose the fact that third-country nationals, refugees, and migrants have already been detained even before applying for asylum. Such detentions are not in line with international and European standards for the protection of human rights and refugees. After the amendment of the asylum legislation, the number of applications decreased significantly, so that in 2017 there were 3,397 asylum applications, and the measure restricting freedom of movement was imposed in 1,567 (46.12\%) cases, of which in $391(11.51 \%)$ cases a detention measure was imposed, while in $1,176(34.61 \%)$ cases an alternative detention measure was imposed.

The trend of declining asylum applications decreased in 2018 as well, with only 670 applications submitted that year, and in $14(2.08 \%)$ cases a measure restricting freedom of movement was imposed, of which in 7 (1.04\%) cases a detention measure was imposed and in $7(1.04 \%)$ cases alternative detention measures were imposed. In 2019, 468 asylum applications were filed, and in 40 (8.54\%) cases a measure restricting freedom of movement was imposed, with an alternative measure of detention being imposed in all $40(8.54 \%)$ cases, whereas the measure of detention was not imposed in any case.

It can be concluded that Hungary experienced a large influx of refugees and migrants to its territory after 2015 and reacted completely unprepared in 2016 when it imposed a measure restricting freedom of movement in 57,517 cases, but not only for asylum seekers - as the number of applications was 29,432, which does not correspond to the possible actual situation. This would mean that in 28,085 $(48.82 \%)$ cases a measure restricting freedom of movement was imposed on thirdcountry nationals who did not apply for asylum or the Hungarian authorities did not credibly register asylum seekers, which ultimately led to data discrepancies. After 2017, the number of asylum applications started to decrease, following the new asylum legislation, which has been criticized by the European courts and other EU bodies as unlawful. As the number of asylum applications decreased, so did the number of cases in which a measure restricting freedom of movement was imposed. It is evident that not a single asylum seeker was detained in 2019, but these are certainly not real indicators of the situation, as Hungary does not consider the placement of asylum seekers in transit zones as a form of deprivation of liberty, and therefore such detention is not included in the statistics of detention measures, which will have to change following the latest CJEU judgment. 
Both the ECtHR and the CJEU have ruled on the lawfulness of detaining asylum seekers in Hungary in several cases. In each of them, they found the basis for the unlawfulness of such deprivation of liberty, especially after changes in legislation caused by the refugee and migration crisis in the EU. In that regard, in Lokpo and Touré v. Hungary, the ECtHR found that the absence of a detailed explanation of the deprivation of liberty of an asylum seeker rendered that measure incompatible with the legality requirement inherent in Article 5 of the ECHR. Therefore, in the Court's view, the detention of the asylum seeker cannot be considered "lawful" within the meaning of Article $5 \$ 1$ (f) of the ECHR. ${ }^{47}$ Shortly after that judgment, the ECtHR found in the cases of Al-Tayyar Abdelhakim v. Hungary and Hendrin Ali Said and Aras Ali Said v. Hungary that there had been a violation of Article $5 \$ 1$ (f) of the ECHR because asylum seekers had been deprived of their liberty for a longer period. After all, the refugee authorities did not initiate their release. The ECtHR concluded that the procedure followed by the Hungarian authorities had the same shortcomings as the case of Lokpo and Touré. ${ }^{48}$ As Szuhai and Tálas state, the authorities in Hungary, as in the other Member States, do not know how to address the issues arising from the migration and refugee crisis, and the governments of those countries are unable to solve structural problems. To change this, the states must have economically functioning institutions with stable governance to cope with pressures such as mass influx. ${ }^{49} \mathrm{Vajkai}$ believes that the issue of migration should be discussed as a matter of security policy in every Member State..$^{50}$

It can be concluded that the decisions imposing the detention measure are molded and that their imposition lacks individual reasoning as to the lawfulness and proportionality of the detention and does not take into account the individual circumstances of each case, including the vulnerability of the individual. Necessity tests and proportionality analyses were not used in all cases and alternatives to detention were sometimes not even considered. Such claims are confirmed by the $\mathrm{CJEU}$ in the judgment of O.M. v. Hungary ${ }^{51}$ where it was found that the measure

47 ECtHR - Lokpo and Touré v. Hungary, Application No. 10816/10.

48 ECtHR - Al-Tayyar Abdelhakim v. Hungary, Application No. 13058/11; ECtHR - Hendrin Ali Said and Aras Ali Said v. Hungary, Application No. 13457/11.

49 See: Szuhai, I., Tálas, P., A 2015-ös európai migrációs és menekültválság okairól és hátteréröl, in: Talas, P. (ed.), Magyarország és a 2015-ös európai migrációs válság, Dialóg Campus Kiadó Budapest, 2017, p. 9-35.

50 See: Vajkai, E. I., A migrációs válság biztonságpolitikai aspektusai, in: Talas, P. (ed.), Magyarország és a 2015-ös európai migrációs válság, Dialóg Campus Kiadó Budapest, 2017, p. 35-49.

51 O.M. v. Hungary [2016] Application No. 9912/15. 
of detention of vulnerable asylum seekers is not sufficiently individualized. ${ }^{52}$ The latest judgment of the CJEU is related to the imposition of a detention measure and its duration in the case of FMS and others v. Országos Idegenrendeszeti Főigazgatóság Dél-alföldi Regionalális Igazgatóság and Országos Idegenrendeszeti Főigazgatóság. ${ }^{53}$

\subsection{Judgment of the CJEU - FMS and others v. Országos Idegenrendeszeti Főigazgatóság Dél-alföldi Regionalális Igazgatóság and Országos Idegenrendeszeti Főigazgatóság}

Afghan nationals (C-924/19 PPU) and Iranian nationals (C-925/19 PPU) who entered Hungary via Serbia applied for asylum at the Röszke transit center located on the Serbian-Hungarian border. Under Hungarian law relating to a safe third country, these applications were rejected as inadmissible, and decisions were taken requiring the applicants to return to Serbia. However, Serbia refused to readmit the applicants to its territory, arguing that the conditions set out in the Agreement between the European Community and the Republic of Serbia on the readmission of persons residing without authorization were not met. ${ }^{54}$ Following that decision, the Hungarian authorities did not examine the substance of the application, but the countries of destination listed in the initial return decision were also amended to include the asylum seekers' country of origin. After that, the asylum seekers filed complaints in relation to these changes, and brought a lawsuit before the Hungarian court requesting the annulment of the return decisions. They also covered the issue of their long-term detention in the transit zone as well as the material reception conditions. According to the judgment of the CJEU, "by administrative decision of 25 April 2019, the asylum authority rejected the application for asylum made by FMS and FNZ, without examining its substance, as inadmissible on the basis of Article 51(2)(f) of the Law on the right of asylum, on the ground that the applicants had arrived in Hungary via a third country on whose territory

52 The Court has found that Article 5 (1) (b) of the ECHR cannot serve as a legal basis for detaining asylum seekers. The Court therefore unanimously ruled that the detention of the asylum seekers was arbitrary and unjustified, in breach of Article 5 (1) of the ECHR. In particular, the Court found that the Hungarian authorities had not made an individualized assessment and had taken into account the applicant's vulnerability in detention on the basis of his sexual orientation. The Court emphasized the special care that the authorities should take when deciding on deprivation of liberty in order to avoid situations that could create a bad environment due to which asylum seekers are forced to flee.

53 Case Szegedi Közigazgatási és Munkaügyi Bíróság - Mađarska - FMS, FNZ (C-924/19 PPU), SA and SA junior (C-925/19 PPU) v. Országos Idegenrendészeti Főigazgatóság Dél-alföldi Regionális Igazgatóság, Országos Idegenrendészeti Főigazgatóság [2020] SL C 161.

54 Agreement between the European Community and the Republic of Serbia on the readmission of persons residing without authorisation, annexed to the Council Decision, 2007, OJ 2007 L 334. 
they were not exposed to persecution justifying recognition of refugee status or to a risk of serious harm justifying the grant of subsidiary protection and that they were guaranteed sufficient protection in the countries through which they had travelled before arriving in Hungary. By that same decision, the asylum authority asserted that the principle of non-refoulement did not apply in the case of those applicants in connection with Afghanistan and ordered that they be removed to Serbia". ${ }^{55}$ As further stated, "FMS and FNZ brought an action before the referring court, requesting it to annul those orders and to order the asylum authority to conduct a fresh procedure, claiming, first of all, that those orders constitute return decisions which must be amenable to a judicial action and, next, that those return decisions are illegal. FMS and FNZ claim that the asylum authority ought to have examined the substance of their application for asylum since they had not been readmitted to the territory of Serbia and since Article 51(2)(f) of the Law on the right of asylum introduces a new concept of 'safe country of transit', which is contrary to EU law. In addition, FMS and FNZ brought an administration action for failure to act before the referring court against the aliens policing authority at first instance, seeking a declaration that that authority failed to fulfil its obligations by not assigning them accommodation outside the Röszke transit zone." 56 Such treatment is contrary to Article 27 of the Hungarian Constitution as well as Article $14 \$ 4$, which guarantees the right to asylum. Szegedi Közigazgatási és Munkaügyi Bíróság (Administrative and Labor Court in Szeged, Hungary) decided to stay the proceedings and to refer the following preliminary questions to the CJEU for a finding of irregularities in the actions of the Hungarian authorities and the administrative court in the areas of asylum, detention in transit zones and freedom of movement.

The CJEU has primarily examined the situation of persons in the Röszke transit center, in the light of the rules governing the detention of asylum seekers and the rules of the Return Directive relating to the illegal stay of third-country nationals. In this connection, the CJEU first found that the detention of an asylum seeker in a transit zone must be considered as a measure restricting freedom of movement, i.e. deprivation of freedom of movement equivalent to imposing a measure of detention. Coming to this conclusion, the CJEU argued that the notion of "detention" in a transit zone means a coercive measure that presupposes deprivation of liberty rather than mere restriction of the person's freedom of movement and isolation of that person from the rest of the population, requiring the person concerned to remain within a confined and closed area. ${ }^{57}$ According to the CJEU, the

Case C-924/19 PPU and C-925/19 PPU, op. cit. note 53., par. 51.

Ibid.,par. 59-60.

Ibid.,par. 231. 
conditions prevailing in the Röszke transit zone constitute deprivation of liberty, inter alia because the asylum seekers cannot leave the zone legally and of their own free will. ${ }^{58}$ The Court also considered whether such detention complied with the requirements of European law and found that, under Article 8 of the Reception Conditions Directive and Article 15 of the Return Directive, neither an asylum seeker nor a third-country national in return could be detained solely because they cannot provide for their own needs as they do not have sufficient means to cover the cost of living on their own. ${ }^{59}$

The CJEU has ruled that Article 33 of the Procedures Directive should be interpreted as precluding any national rule allowing the rejection of an application for international protection as inadmissible, merely because the applicant came to the territory of a Member State through a country where he or she was not exposed to persecution or a risk of serious harm within the meaning of a national provision transposing Article 15 of Directive 2011/95, or in which a sufficient level of protection is guaranteed ${ }^{60}$ Importantly, the CJEU has pointed out that the principle of the supremacy of EU law, as well as the right to effective judicial protection guaranteed by Article 47 of the EU Charter, must be interpreted as requiring the national court, in the absence of a national provision providing for judicial review of the lawfulness of an administrative decision ordering the detention of an asylum seeker or third-country national whose applications for asylum have been rejected, to declare that it has jurisdiction to decide on the lawfulness of such detention and authorize that court to release the person concerned immediately if it considers that the detention is contrary to EU law. The same rule was set in the absence of a national provision providing for judicial review of the right to accommodation within the meaning of Article 17 of the Reception Directive, i.e. the CJEU orders the national court to declare itself competent to rule on a remedy intended to guarantee such a right. ${ }^{61}$

It therefore follows from this judgment that detention in a transit zone is no longer lawful after four weeks and that the conditions prevailing in transit zones indisputably lead to them fulfilling all the conditions of detention and deprivation of liberty, which is contrary to positive EU legislation. With this judgment, the CJEU has given great powers to national courts. It is also very important that the CJEU states that it is not lawful to reject an asylum application because the applicant entered the territory of a certain Member State through the territory of

\footnotetext{
$58 \quad$ Ibid., par. 229.

59 Ibid., par. 266.

60 Ibid., par. 165.

${ }^{61} \quad$ Ibid., par. 301.
} 
a Member State where his or her life was not endangered, i.e. safe third countries. It is very clear that the CJEU states that the application of the institution of a safe third country, as introduced in Hungarian legislation, is illegal when used as a pretext for taking responsibility for refugees.

With this ruling, the EU has taken a major step for the Member States whose laws have not given administrative courts the power to overturn a decision to detain an asylum seeker, but only to return it to a review body with a more advisory role. One of these countries is Croatia, whose legal framework stipulates that decisions based on the discretion of administrative bodies, such as the issue of asylum and detention, cannot be overturned by administrative courts. Such a decision of the CJEU will certainly have an impact on the amendment of certain procedural issues and legislative provisions of national laws. This decision was preceded by the ECtHR judgment in Ilias and Ahmed v. Hungary, which found that Hungary had breached its human rights obligations by returning an asylum seeker to Serbia without considering the risk that he might be subjected to inhuman and degrading treatment upon arrival. ${ }^{62}$ The CJEU goes beyond the ECtHR and finds that detention in the Röszke transit zone without a formal decision and appropriate safeguards constitutes arbitrary detention. ${ }^{63}$ Notwithstanding court decisions, the Hungarian Migration and Asylum Office ignored court rulings and continued to designate a transit zone as a place to detain asylum seekers under the same conditions as before the ECtHR and CJEU decisions. ${ }^{64}$

\section{DETENTION UNDER THE NEW PACT ON MIGRATION AND ASYLUM}

Three key pieces of European legislation relating to the detention of asylum seekers are subject to the reform proposed by the new PMA, namely the Reception Conditions Directive, the Return Directive, and the Dublin III Regulation. All three of these changes tend to make detention conditions more severe. Three main trends can be observed. The first is the increased use of detention measures on a wider range of grounds, the second is the expansion of other measures that restrict the freedom of movement of asylum seekers, other than detention, and the third is certainly related to problematic conditions in detention facilities. These trends lead to a large gap between the development of the CEAS and the protection of human rights, as the greatest human rights violations occur precisely in connec-

\footnotetext{
62 Case Ilias and Ahmed v. Hungary [2019] Application No. 47287/15.

63 Case C-924/19 PPU and C-925/19 PPU, op. cit. note 53., par. 248.

64 See: Hungarian Helsinki Committee, The Immigration and asylum office continues to ignore court decisions and interim measures, 2018.
} 
tion with the detention of asylum seekers. ${ }^{65}$ The Return Directive introduced an additional basis for detention if a third-country national poses a risk to public policy, public security, or national security. Furthermore, Member States are required to set a maximum detention period at three months, a change which the Commission justifies by referring to the ineffectiveness of return policies. The proposed changes to the risk of absconding and the mandatory denial of the period of voluntary return also have implications for the right to liberty. Further changes to the legal framework governing the detention and accommodation of applicants for international protection are provided for in the proposal for a Regulation on Asylum and Migration Management, which replaces the Dublin III Regulation. The deadlines applicable to relocation procedures are also changed if a detention measure is used, which in most cases means stricter deadlines. ${ }^{66}$

The Commission's proposal for a revised Reception Conditions Directive introduces changes to the legal framework governing freedom of movement and detention during the asylum procedure, as in the current Reception Conditions Directive, the general rule of freedom of movement in the territory of a Member State or within the territory assigned to the applicants in that Member State. However, the proposed recast of the Directive provides that the Member States shall grant to asylum seekers a specific place of residence, if necessary for reasons of public interest or public order, for rapid processing and effective monitoring of applications, for rapid processing and effective monitoring of transfer procedures or for the prevention of absconding. The proposal explicitly states that all decisions restricting the freedom of movement of asylum seekers must be based on an individual approach, taking into account any special needs for the reception of applicants and the principle of proportionality. The importance which the Commission attaches to measures restricting freedom of movement is reflected in the fact that Article 8 adds a further ground for detention: where an asylum seeker has been granted a particular place of residence but has not fulfilled his or her obligation to reside in that country, and there is a real risk of absconding, the asylum seeker may be detained to ensure that the obligation to stay in an assigned place is fulfilled. All legal detention requirements and applicable guarantees set out in the current Reception Conditions Directive remain unchanged. This means that the duration of the detention measure must be proportionate and that detention is no longer allowed if there are no longer indications that an asylum seeker will not fulfill the

65 REMAP Study First Edition, Chapter 2 - Ensuring Liberty and Freedom of Movement, 2020, p. 41.

66 Caritas Europa's analysis and recommendations on the EU Pact on Migration and Asylum, Position Paper, Caritas Europa, available at: [https://www.caritas.eu/wordpress/wpcontent/uploads/2021/02/210212_position_Paper_EU_Pact_migration_Caritas_Europa_Final.pdf], Accessed 12 January 2021. 
obligation to stay in an assigned place. Cornelisse, therefore, considers that measures to detain and restrict freedom of movement, if decided by an administrative body, should also be subject to swift judicial review, and the scope of such review should be such as to enable the judicial authority to substitute its own decision for the administrative authority's decision. Also, he believes that it is necessary to amend the Commission's proposal for a new PMA if real protection, promised security, and decent conditions are to be achieved because this proposal does not contribute to the protection of asylum seekers. ${ }^{67}$

In their recent joint commentary on the new PMA proposal, Greece, Spain, Malta, and Italy warn that, although the Commission's proposal does not explicitly include this possibility, we must be sure that the final regulation of border procedures does not pave the way to undesirable effects. According to their comments, the establishment of large closed centers at the external borders is not acceptable and they note that the proposed asylum and migration management must fully respect human rights and the rights of asylum seekers. ${ }^{68}$

The new PMA does not define or explicitly mention detention, but that does not mean that it excludes it from the application. On the contrary, it tacitly tightens the rules of detention and leads to the fact that detention is no longer used as a last resort, but as a necessary measure in the procedure that takes place at the border. According to Wessels, this proposal seems to run counter to the ECtHR's position on the interpretation of Article 5 of the ECHR. Wessels considers that a closer examination of the text of those provisions which could serve as a basis for detention and the asylum procedure (Article 8(3)(d) of the Commission proposal to amend the Reception Conditions Directive) and for the border return procedure (Article 41(a) (5) of the proposal to amend the Common Procedures Directive) largely reflects the wording of Article 5 (1) (f) of the ECHR concerning the prevention of unauthorized entry. The proposal appears to have been shaped by that standard. In this context, if the detention is possible during border proceedings under Article 5(1)(f), it is important that entry has not yet been declared authorized. ${ }^{69}$ However, as the REMAP study shows, Article 5 of the ECHR is not in

67 See: Carrera, S., The Pact and Detantion: An Empty Promise of "certainty, clarity and decent conditions", Special series of post on the New Migration Pact, coordinated by Prof. Daniel Thym, EU Immigration and Asylum Law and Policy, 2020.

68 New Pact on Migration and Asylum: comments by Greece, Italy, Malta and Spain, available at: [http:// www.astrid-online.it/static/upload/2511/251120-non-paper-pacto-migratorio.pdf], Accessed 12 January 2021.

69 Wessels, J., The New Pact on Migration and Asylum: Human Rights challenges to border procedures., Online publication or Website, RLI Blog on Refugee Law and Forced Migration, available at: [https:// rli.blogs.sas.ac.uk/2021/01/05/the-new-pact-on-migration-and-asylum-human-rights-challenges-toborder-procedures/], Accessed 14 January 2021. 
line with international human rights law. The prohibition of arbitrary detention is a well-established rule of customary international law and is codified in a wide range of treaties, such as Article 9 of the International Covenant on Civil Rights. Also, based on case law and General Comments, the Human Rights Committee explained that the detention of asylum seekers is only allowed for a short period to document their entry, record their claims and establish their identity. ${ }^{70}$ It has been proposed to detain asylum seekers in the screening or rapid verification process for a maximum of 5 days, but if, for example, the identity could not be established for months, it remains unclear how much the procedure is expected to be shortened and what happens when these deadlines are exceeded. According to Carrera, one of the problems is that this period can be extended to 12 weeks in cases where individuals appeal against a decision rejecting an application for international protection and can be further extended, depending on the time required to prepare the return procedure or implement expulsion proceedings. ${ }^{71}$ Besides, the detention of asylum seekers at the EU border during the international protection processing according to all international standards should be considered arbitrary, unless there are specific reasons identified in each case, after which it is considered necessary to impose a detention measure. The whole proposal is based on the fact of illegal entry and prevention of illegal entry, but the illegal entry should not be the basis and justification for detaining asylum seekers. It can be concluded that, with this proposal, the objective of asylum policy, instead of a common way of creating uniform rules and harmonizing procedures, has become the fight against illegal entry into the EU. Such an objective cannot lead to a quality and harmonized asylum policy. The EU is legally bound to follow the rules of customary international law, which are an integral part of the EU legal order and binding on its legislators. However, the new PMA would allow the detention of third-country nationals in order to assess their claims, such as those coming from a country of origin with a recognition rate of less than $20 \%$, without specific individual reasons. ${ }^{72}$

It can therefore be concluded that the Commission's proposal provides for detention in the event of illegal entry or during the processing of asylum applications, which is not in line with international law and the obligations that the EU must fulfill. It is therefore necessary to amend such a proposal and to derogate from keeping the asylum seekers at the borders only on the grounds of attempted illegal entry and for the purpose of the asylum procedure. The proposal for a Regulation

\footnotetext{
70 REMAP Study First Edition, Chapter 2 - Ensuring Liberty and Freedom of Movement, 2020.

71 Carrera, S., Whose Pact? The Cognitive Dimensions of the New EU Pact on Migration and Asylum, CEPS Policy Insights, No. 2020-22, 2020, p. 4, available at: [https://www.ceps.eu/wp-content/uploads/2020/09/PI2020-22-New-EU-Pact-on-Migration-and-Asylum.pdf], Accessed 14 April 2021.

72 Wessels, op. cit., note 67.
} 
addressing situations of crisis and force majeure in the field of migration and asylum refers to provisions on the adaptation of new tools for managing migration at the border in exceptional situations, some of which have consequences for the right to liberty. In the event that a mass influx of irregular arrivals floods the Member State's asylum, reception, or return systems and thus jeopardizes the functioning of the CEAS, derogations from the proposed Asylum Procedures Regulation are allowed, meaning that the asylum and return procedures may be extended for an additional period of 8 weeks. The preamble to the Regulation clarifies that detention should also be possible during this period, following Article 41(a) of the proposed Asylum Procedures Regulation concerning the border return procedure. Moreover, the proposed Regulation addressing situations of crisis and force majeure in the field of migration and asylum introduces two additional cases in which the risk of absconding can be presumed in individual cases unless proven otherwise. Such a presumption may subsequently provide a basis for the use of detention under Article 18 of the proposed recast of the Return Directive. Two additional grounds are an explicit expression of intent not to comply with returnrelated measures or a gross failure to comply with the obligation to cooperate in the proceedings. ${ }^{73}$

When it comes to respecting the right to personal liberty, perhaps the most striking feature of the PMA is the implicit blurring of the line between detention and restriction of freedom of movement, a tendency that is undoubtedly typical of modern migration management. The most important question raised by such practices is how well our current framework of fundamental rights can respond to the challenges that arise from it. Checks and border procedures are characterized by refusal of entry. At the same time, applicants for international protection have the right to remain under EU law and cannot return before their application is assessed. Moreover, Article 18 of the EU Charter provides for the right to asylum. This special construction of detention at the border inevitably affects the freedom of asylum seekers at the border or in the transit zone. In fact, in these proceedings, entry is refused precisely to prevent free movement within the territory of a Member State, as well as potential secondary movements within the EU.

The policy of non-entry into the EU, as provided for in the control and border asylum and return procedures, interferes with the right to personal liberty and also raises complex factual and legal questions. Such solutions will certainly harm the human rights of asylum seekers, noting that in 2013 the European Commission delivered an opinion stating that border procedures can only be used in exceptional circumstances because they involve keeping asylum seekers and unaccom-

73 See: Carrera, op. cit., note 65. 
panied minors. It can therefore be concluded that the detention of asylum seekers at the EU external borders will constitute a deprivation of liberty and not a mere restriction on freedom of movement, and the measure of detention will no longer be the exception but the rule. It is therefore necessary to address the amendments to the PMA with a view to finding a solution for developing and strengthening the CEAS that protects the human rights of asylum seekers

\section{CONCLUSION}

After the migration and refugee crisis, Hungary was a state that changed its legislation regarding the granting of international protection and began the practice of conducting asylum procedures exclusively in transit zones, thus automatically detaining asylum seekers, although Hungary did not consider this a deprivation of liberty. This paper therefore analyzes Hungary's treatment of asylum seekers, and then proceeds to examine the case law of the CJEU in the case of FMS and others v. Országos Idegenrendeszeti Főigazgatóság Dél-alföldi Regionalális Igazgatóság and Országos Idegenrendesgat Fö. What the CJEU has found is that leaving people in transit zones without the right to free movement is to be considered detention, even though they are not specialized detention facilities. It can be concluded that the research has shown that Hungary's actions following the migration and refugee crisis and the changes in legislation related to the rights of asylum seekers are in complete contradiction with European and international legal norms when it comes to restricting the freedom of movement of asylum seekers and applying detention measures. To date, Hungary has not changed its treatment of asylum seekers in transit zones, although the CJEU has made it clear that such detention of asylum seekers must be stopped immediately. With this ruling, the CJEU has taken a major step towards protecting the rights of asylum seekers when it comes to freedom of movement within the country in which they have sought asylum. Shortly after the Court ruling, the EU proposed a number of changes that it introduced into the new PMA to improve the existing asylum and migration management system. After analyzing the provisions of the PMA related to the detention of asylum seekers in the border procedure, it was found that they do not contribute to the CEAS and the protection of the human rights of asylum seekers, but represent a step backwards. The provisions on the implementation of the asylum procedure at the EU border, as well as the automatic detention of an asylum seeker during that time, are in line with the recent case law of the CJEU. With the adoption of the new PMA, the EU will not compromise the protection of the rights of refugees and asylum seekers in any way when it comes to restricting freedom of movement and detention, and detention will no longer be used as an "ultima ratio" but as a "prima ratio" necessary to carry out border asylum 
procedures. The provisions of the new PMA regarding detention violate the human rights of refugees and asylum seekers. Efforts must be made to amend such a pact, especially when it comes to vulnerable groups of asylum seekers such as children and unaccompanied minors, in order to protect the human rights of refugees and asylum seekers at the highest level. Preventing illegal migration cannot be the main objective of the new PMA, but the focus must be on protecting human rights and the rights of refugees, because that is the primary goal of the institution of asylum and should be the primary goal of the EU.

\section{REFERENCES}

\section{BOOKS AND ARTICLES}

1. Bender, D.; Hocks, S., Eilrechtsschutz und Selbsteintrittspflicht im Dublin-Verfahren, Asylmagazin, 2010

2. Carrera, S., The Pact and Detention: An Empty Promise of "certainty, clarity and decent conditions", Special series of post on the New Migration Pact, coordinated by Prof. Daniel Thym, EU Immigration and Asylum Law and Policy, 2020

3. Costello, C., Human Rights of Migrants and Refugees in European Law, Oxford University Press, 2016

4. De Bruycker, P.; Bloomfield, A.; Tsourdi, E. L.; Pétin, J., Alternatives to Immigration and Asylum Detention in the EU - Time for Implementation, Odysseus - Academic Network for Legal Studies on Immigration, 2015

5. Filzwieser, C.; Sprung, A., Dublin III-Verordnung, Das Europäische Asylzuständigkeitsystem Stand: 1. February 2014, BWV Berliner-Wissenschaft, 2014

6. Hruscha, B.; Maiani, F., Regulation (EU) No 604/2013 of the European Parliament and of the Council of 26 June 2013 establishing the criteria and mechanisms for determining the Member State responsible for examining an application for international protection lodged in one of the Member States by a third-country national or a stateless person (recast), in: Hailbronner, K.; Thym D., (eds.), EU Immigration and Asylum Law, A Commentary, 2nd edition, C.H.Beck/Hart/Nomos, 2016, pp. 1478-1604

7. Maiani, F., The Dublin III Regulation: A New Legal Framework for a More Humane System?, in: Chetail, V.; De Bruycker, P.; Maiani, F. (eds.), Reforming the Common European Asylum System - The New European Refugee Law, Brill Nijhoff, Leiden, Boston, 2016, pp. $99-142$

8. Marx, R, Article 26, in: Zimmermann, A. (ed.), The 1951 Convention Relating to the Status of Refugees and its 1967 Protocol: A Commentary, Oxford University Press, 2011, pp. 1147-1164

9. Meyer, H., Mindestanfnahmebedingungen für Asylbewerber: Nivelierung aufniedrigem Niveau oder Fortschritt für eine gemeinsame Asylpolitik in Europa?, in: Neue Zeitschrift für Verwaltungsrecht, Nr. 4, 2004, pp. 547-551 
10. Peek, M.; Tsourdi, L., Asylum Reception Conditions Directive 2012/33/EU, Article 7, in: Hailbronner, K.; Thym, D., (eds.), EU Immigration and Asylum Law, A Commentary, 2nd edition, C. H. Beck/Hart/Nomos, 2016, pp. 1381-1477

11. Szuhai, I.; Tálas, P., A 2015-ös európai migrációs és menekültválság okairól és hátteréröl, in: Talas, P. (ed.), Magyarország és a 2015-ös európai migrációs válság, Dialóg Campus Kiadó Budapest, 2017, pp. 9-34

12. Vajkai, E. I., A migrációs válság biztonságpolitikai aspektusai, in: Talas, P. (ed.), Magyarország és a 2015-ös európai migrációs válság, Dialóg Campus Kiadó Budapest, 2017, pp. 35-48

13. Wilsher, D., Immigration Detention: Law, History, Politics, Cambridge University Press, 2012

\section{COURT OF JUSTICE OF THE EUROPEAN UNION}

1. Case C-61/11 Hassen El Dridi, alias Soufi Karim [2011] ECLI: 268

2. Case Szegedi Közigazgatási és Munkaügyi Bíróság - Mađarska - FMS, FNZ (C-924/19 PPU), SA and SA junior (C-925/19 PPU) v. Országos Idegenrendészeti Főigazgatóság Délalföldi Regionális Igazgatóság, Országos Idegenrendészeti Főigazgatóság [2020] SL C 161

\section{ECHR}

1. European Convention for the Protection of Human Rights and Fundamental Freedoms, as amended by Protocols Nos. 11 and 14, 4 November 1950, ETS 5

2. Ahmed AYAD v. Hungary and four joint applications [2015] Application No. 7077/15, 26250/15, 26819/15, 32038/15, 48139/16

3. Al-Tayyar Abdelhakim v. Hungary, Application No. 13058/11

4. Case Ilias and Ahmed v. Hungary [2019.] Application No. 47287/1

5. Dragon Dshirji v. Hungary [2016] Application No. 21325/16

6. Hendrin Ali Said and Aras Ali Said v. Hungary, Application No. 13457/11

7. Lokpo and Touré v. Hungary, Application No. 10816/10

8. O.M. v. Hungary [2016] Application No. 9912/15

9. S.B. v. Hungary [2017] Application No. 15977/17

\section{INTERNATIONAL LAW}

1. International Covenant on Civil and Political Rights, 16 December 1966, United Nations, Treaty Series, vol. 999

2. Convention relating to the Status of Refugees, adopted on 28 July 1951 by General

3. Assembly Resolution 429 (V) of 14 October 1950, entered into force on 22 April 1954

\section{EU LAW}

1. Amended proposal for a Regulation of the European Parliament and of the Council establishing a common procedure for international protection in the Union and repealing Directive 2013/32/EU, COM (2020) 611 final 
2. Consolidated versions of the Treaty on the Functioning of the European Union Protocol (No 2) on the application of the principles of subsidiarity and proportionality, OJ C 202

3. Council Directive 2004/83/EC on minimum standards for the qualification and status of third-country nationals or stateless persons as refugees or otherwise in need of international protection and on the content of the protection granted, 2004, OJ L 304

4. Directive 2008/115/EC of the European Parliament and of the Council of 16 December 2008 on common standards and procedures in Member States for returning illegally staying third-country nationals, OJ L 348

5. Directive 2011/95/EU of the European Parliament and of the Council of 13 December 2011 on standards for the qualification of third-country nationals or stateless persons as beneficiaries of international protection, for a uniform status for refugees or for persons eligible for subsidiary protection, and for the content of the protection granted (recast), OJ L 337

6. Directive 2013/32/EU of the European Parliament and of the Council of 26 June 2013 on common procedures for granting and withdrawing international protection, OJ L 180

7. Directive 2013/33 / EU of the European Parliament and of the Council of 26 June 2013 laying down standards for the reception of applicants for international protection (recast) OJ L 180

8. Proposal for a Regulation of the European Parliament and of the Council on crisis and force majeure situations in the field of migration and asylum, COM (2020) 613 final

9. Proposal for a Regulation of the European Parliament and of the Council on asylum and migration management and amending Council Directive 2003/109 / EC and the proposed Regulation (EU) XXX / XXX [Asylum and Migration Fund], COM (2020) 610 final

10. Proposal for a Regulation of the European Parliament and of the Council introducing indepth checks on third-country nationals at the external borders and amending Regulations (EC) no. 767/2008, (EU) 2017/2226, (EU) 2018/1240 and (EU) 2019/817, COM (2020) 612 final

11. Regulation (EU) No 604/2013 of the European Parliament and of the Council of 26 June 2013 establishing the criteria and mechanisms for determining the Member State responsible for examining an application for international protection lodged in one of the Member States by a third-country national or a stateless person, OJ L 180

\section{LIST OF NATIONAL REGULATIONS, ACTS AND COURT DECISIONS}

1. Act LXXX of 2007 on Asylum 2007. évi LXXX Törvény a menedékjogról Asylum Act, , Amended by Act XXXIX of 2016 on the amendment of certain acts relating to migration and other relevant acts 2016. évi XXXIX. törvény egyes migrációs tárgyú és ezekkel összefüggésben más törvények módosításáról, Amended by: 2016. évi XCIV. törvény a határon lefolytatott menekültügyi eljárás széles körben való alkalmazhatóságának megvalósításához szükséges törvények módosításáról

2. Magyarország Alaptörvénye, Magyar Közlöny Lap- ésKönyvkiadó, Majláth Zsolt László, 2011

3. Nyírbátor District Court, Decisionsno.1.Ir.214/2014/3., 9.Ir.350/2014/3., 1.Ir.728/2013/5. and 9.Ir.335/2014/3 
4. Nyírbátor District Court, Decisionno. 1.Ir.46/2014/3., Debrecen District Court, Decisionsno. 68. Beü.94/2014/4-I., 68.Beü.108/2014/4, 68.Beü.104/2014/4. and 68.Beü.1087/2014/4

5. Supreme Court, Advisory Opinion of the Hungarian Supreme Court, adopted on 30 May 2013 and approved on 23 September 2013

6. Supreme Court, Advisory Opinion of the Hungarian Supreme Court, adopted on 30 May 2013 and approved on 23 September 2013

7. District Court of Szeged, Decision no. 6.K.27.060/2018/8; District Court of Szeged, Decision no. 44.K.33.689/2018/11

\section{OTHER SOURCES}

1. Hungarian Helsinki Committee, Information Note on asylum-seekers in detention and in Dublin procedures in Hungary, 2014

2. FRA and Council of Europe, Handbook on European Law relating to asylum, borders and immigration, 2013

3. Agreement between the European Community and the Republic of Serbia on the readmission of persons residing without authorisation, annexed to the Council Decision, 2007, OJ 2007 L 334

4. Hungarian Helsinki Committee, The Immigration and asylum office continues to ignore court decisions and interim measures, 2018

5. REMAP Study First Edition, Chapter 2 - Ensuring Liberty and Freedom of Movement, 2020

\section{WEB SOURCES}

1. Asylum Information Database, Country Report: Hungary, European Council of Refugees and Exiles, available at: [https://www.asylumineurope.org/reports/country/hungary],_ Accessed 1 March 2021

2. Asylum Information Database, Country Report 2015.: Hungary, European Council of Refugees and Exiles, available at: [https://www.asylumineurope.org/sites/default/files/reportdownload/aida_hu_update.iv__0.pdf], Accessed 1 March 2021

3. Caritas Europa's analysis and recommendations on the EU Pact on Migration and Asylum, Position Paper, Caritas Europa, available at: [https://www.caritas.eu/wordpress/wpcontent/ uploads/2021/02/210212_position_Paper_EU_Pact_migration_Caritas_Europa_Final. pdf], Accessed 1 March 2021

4. Carrera, S., Whose Pact? The Cognitive Dimensions of the New EU Pact on Migration and Asylum, CEPS Policy Insights, No. 2020-22, 2020, available at: [https://www.ceps.eu/wpcontent/uploads/2020/09/PI2020-22-New-EU-Pact-on-Migration-and-Asylum.pdf], Accessed 1 March 2021

5. Commissioner for Human Rights Of The Council Of Europe, Report following visit to Hungary from 4 to 8 February 2019, 2019., available at: [http://bit.ly/30upiLp], Accessed 1 March 2021 
6. CPT, Report on the visit to Hungary from 20 to 26 October 2017, CPT/Inf (2018) 42, 18 September 2018, available: [https://bit.ly/2TTgsTq.], Accessed 1 March 2021

7. European Commission, Migration and Asylum: Commission takes further steps in infringement procedures against Hungary, 2018., available at: [https://bit.ly/2uMEJ2c.], Accessed 1 March 2021

8. Human Rights Committee, Concluding observations on the sixth periodic report of Hungary, CCPR/C/HUN/CO/6, 2018., available at: [https://bit.ly/2TWDzwu.], Accessed 1 March 2021

9. Hungarian Helsinki Committee, Access to Protection Jeopardized - Information note on the treatment of Dublin returnees in Hungary, 2011, Chapter 4-5., available at: [http:// helsinki.hu/en/access-to-protection-jeopardised-2], Accessed 1 March 2021

10. Hungarian Helsinki Committee, Briefing paper for the European Committee for the Prevention of Torture and Inhuman or Degrading Treatment or Punishment (CPT) on the occasion of the CPT's periodic visit to Hungary, 2013, Chapter 5.1, available at: [http://helsinki.hu/wp-content/uploads/HHC_briefing-paper_CPT_periodic_visit_28March2013_ FINAL.pdf], Accessed 1 March 2021

11. Hungarian Helsinki Committee, Stuck in Jail - Immigration detention in Hungary in 2010/2011, available at: [http://helsinki.hu/wp-content/uploads/HHC-immigration-detention_ENG_final.pdf], Accessed 1 March 2021

12. New Pact on Migration and Asylum: comments by Greece, Italy, Malta and Spain, available at: [http://www.astrid-online.it/static/upload/2511/251120-non-paper-pacto-migratorio. pdf], Accessed 1 March 2021

13. OHCHR, End of visit statement of the UN Special Rapporteur on the human rights of migrants, Felipe González Morales, 2019., available at: [http://bit.ly/2tqOHcX.], Accessed 1 March 2021

14. UN Office of the High Commissioner for Human Rights, Press briefing notes on Iran and Hungary, 2019., available at: [http://bit.ly/38h8pXr.], Accessed 1 March 2021

15. UNHCR, 'UNHCR Chief visits Hungary, calls for greater access to asylum, end to detention and more solidarity with refugees".2017, available at: [http://bit.ly/2y2BnsC.], Accessed 1 March 2021

16. UNWGAD, 'UN human rights experts suspend Hungary visit after access denied', 15 November 2018, avaiable at: [https://bit.ly/2B7X5Pu], Accessed 1 March 2021

17. Wessels, J., The New Pact on Migration and Asylum: Human Rights challenges to border procedures, Online publication or Website, RLI Blog on Refugee Law and Forced Migration, available at: [https://rli.blogs.sas.ac.uk/2021/01/05/the-new-pact-on-migration-and-asylum-human-rights-challenges-to-border-procedures/], Accessed 1 March 2021 